ISSN 0103-5150

Fisioter. Mov., Curitiba, v. 29, n. 3, p. 449-459, Jul./Set. 2016

Licenciado sob uma Licença Creative Commons

DOI: http://dx.doi.org.10.1590/1980-5918.029.003.A002

(c) (i)

\title{
Functional disability for mobility in adults: a population-based study
}

\author{
Incapacidade funcional para mobilidade em \\ adultos: estudo de base populacional
}

Cristhiane Yumi Yonamine, Tiemi Matsuo, Regina Kazue Tanno de Souza, Mathias Roberto Loch, Marcos Aparecido Sarria Cabrera*

Universidade Estadual de Londrina (UEL), Londrina, Paraná, Brazil

\begin{abstract}
Introduction: Functional disability is an important health indicator associated with worse quality of life. Objective: To estimate the prevalence of functional disability for mobility and to identify factors associated with difficulty going up and down stairs in adults aged 40 years or over. Methods: Cross-sectional, population-based study, with residents of the Municipality of Cambé, PR, interviewed in 2011. The dependent variable was the difficulty of going up and down stairs. Analysis of associated factors was performed using Poisson regression for each subgroup (40 - 59 years and 60 years or older). Results: In total, 24\% of the subjects presented some kind of difficulty going up stairs $(\mathrm{p}<.01)$. In both subgroups, a significantly higher prevalence in women, among those inactive during leisure time and those with a history of cerebrovascular disease was observed. In the subgroup aged 40 to 59 years, age 50 - 59 years, hypertension, diabetes and falls in the previous 12 months were also associated with the outcome. Conclusion: The results suggest the
\end{abstract}

*CYY: MS, e-mail: cyumis@yahoo.com.br TM: PhD, e-mail: tiemi.matsuo@gmail.com RKTS: PhD, e-mail: reginatanno@hotmail.com MRL: PhD, e-mail: mathiasuel@hotmail.com MASC: PhD, e-mail: marcoscabrera@uol.com.br 
need to expand the actions of health promotion, prevention and control of chronic conditions, especially among middle-aged people.

Keywords: Activities of Daily Living. Mobility Limitation. Cross-Sectional Studies.

\section{Resumo}

Introdução: A incapacidade funcional é importante indicador de saúde, associada a pior qualidade de vida. Objetivo: Estimar a prevalência de incapacidade funcional para mobilidade e identificar os fatores associados à dificuldade de subir e descer escadas em adultos de 40 anos ou mais. Metódos: Estudo transversal, de base populacional, com residentes no Município de Cambé-PR, entrevistados em 2011. A variável dependente foi a dificuldade de subir e descer escadas. A análise de fatores associados foi realizada por meio da regressão de Poisson, para cada subgrupo etário (40 a 59 anos e 60 anos ou mais). Resultados: No total, 24\% referiram alguma dificuldade para subir e descer escadas $(p<0,01)$. Em ambos os subgrupos, observaram-se prevalências significativamente mais elevadas em mulheres, entre os inativos no lazer e naqueles com histórico de doença cerebrovascular. No subgrupo com idade entre 40 e 59 anos, associaram-se também ao desfecho a faixa etária de 50 a 59 anos, a hipertensão arterial, o diabetes e queda nos últimos 12 meses. Conclusão: Os resultados apontam a necessidade de ampliar as ações de promoção da saúde e de prevenção e controle das condições crônicas, principalmente entre não idosos.

Palavras-chave: Idoso. Densidade Óssea. Osteoporose. Acidentes por Quedas. Programas de Rastreamento.

\section{Introduction}

Functional disability is the difficulty or need for help in performing basic daily activities necessary for independent living in the community (1). Despite the increased frequency of functional disability in people of advanced age, the reported difficulties are not only related to age (2), since functional disability is characterized as being a multifactorial process (3). Sociodemographic, behavioral and environmental factors and those related to social support are among the factors related to disability that can speed up or slow down the process (4).

The most commonly used measures to evaluate functional capacity are basic activities of daily living (ADL), instrumental activities of daily living (IADL), and mobility. Some authors have shown that restrictions in mobility are predictive of functional disability and therefore can be considered as an early sign of functional decline $(5,6,7,8)$.

This functional deterioration process often begins as early as the fourth decade of life (9), however, studies on functional capacity are carried out predominantly with older adults $(10,11,12,13,14,15)$.

Therefore, this study aimed to evaluate the level of mobility as an early indicator of disability, as well as the factors associated with these difficulties in middle-aged and older adults living in a mediumsized municipality of southern Brazil.

\section{Methods}

Cross-sectional, population-based study, the data of which came from the project "Cardiovascular Diseases in the State of Paraná: risk profile, mortality, medication therapy and complications" (VigiCardio Project), conducted with adults aged 40 years or over, living in the urban area of the municipality of Cambé, Paraná, between February and June 2011. As the 2010 Census data had not been made available at the time of planning of the study, data from the 2007 Population Count was considered to calculate the sample size, which showed a population of 92,888 people, of which $33.1 \%$ were aged 40 or over (16). The value of the prevalence of the outcome was unknown, therefore, to calculate the sample size a prevalence of $50 \%$ was used, with a $3 \%$ margin of error and $95 \%$ confidence interval, resulting in a sample of 1066 subjects. Foreseeing possible losses and refusals, this number was increased by $25 \%$, initially totaling 1332 subjects to be interviewed.

The 86 census sectors in the urban area were included in the study. The number of people to be interviewed in each sector was calculated according to the number of individual residents, based on (i) the proportional distribution of the population in each sector, by gender and age (five-year intervals), and (ii) the data from the population count by the 
IBGE, mentioned above, with reference date of April 1, 2007 (16). For each sector a quota of individuals to be interviewed was defined, for each gender and five-year age group, according to the proportion observed in the population of the municipality. After these procedures and eventual rounding up, the total number of subjects to be interviewed was 1339.

The sampling was carried out in three stages, with the stratification of population by census sectors being the first stage. The number of individuals to be interviewed in each census sector was defined considering the proportional share, i.e., for census sectors with larger representativity in the population a greater number of people were selected, and for the smaller census sectors fewer people were selected. In the second stage, in each census sector, the households were selected through systematic sampling. The blocks of each census tract were listed and the starting point of the route was defined through a draw. After determining the block corresponding to the initial point, the corner of the block was drawn in which the route would begin in a counterclockwise direction. Thus, a contiguous route was randomly selected. The first home was established by draw, and from that home, the next to be selected was the third, i.e., for every two households one was selected, to ensure the representativity of each sector and prevent concentration of respondents in certain streets or blocks. In the third stage, in the household selected, eligible individuals were identified according to gender and age group (five-year intervals). In situations where more than one resident met the conditions a draw was held for the participant selection. Further details regarding the sampling process are described by Souza et al. (17).

Functional disability for mobility was investigated through the difficulty to perform four activities (getting up from the bed to an armchair or a chair, sitting and lying down; walking around the house; walking out of the house; and going up and down stairs) (4). The instrument used to evaluate these activities was the Functional Autonomy Measurement System (SMAF) (18).

Because disability be considered a deficit, the SMAF scores are negatively oriented, and each function can be graded from 0 (autonomy) to -3 (total help or dependence). Thus, the subjects were classified into three categories: no disability (score 0), mild disability (scores $-0.5,-1$ and -1.5 ) and moderate/ severe disability (scores -2 and -3 ).
To verify the association between the variables difficulty going up and down stairs was defined as the indicator of functional disability for mobility, considered to be a reliable predictor in identifying a transition group (pre-clinical disability) that may be more vulnerable to changes in the health status than those who do not present difficulties (11).

The independent variables were divided into two groups: demographic and socioeconomic characteristics (gender, age, marital status, race/color, years of schooling, paid work and economic classification, the latter according to the Associação Brasileira de Empresas de Pesquisa - ABEP) (19) and health-related conditions and behaviors (physical activity during leisure time, self-reported hypertension, diabetes DM, cerebrovascular disease - CVD, musculoskeletal disorders, falls in the last 12 months and nutritional status). All the information was collected through the reports of the participants or their responsible caregivers, through home interviews using a structured form, except for the nutritional status which was calculated by measuring the body mass index (BMI), in which the World Health Organization classification (20) was adopted.

The information was double entered into a database of the Epi Info version 3.5.1 program. In the descriptive analysis, the distribution of frequency and association measures was carried out using Fisher's exact test or the chi-square test. The prevalence of the outcome mild and moderate/severe disability for going up and down stairs were compared to those who did not present any difficulty (reference category), according to the characteristics selected.

The crude and adjusted analyzes of the data were based on the prevalence ratio, using Poisson regression with robust variance, for each variable with the outcome (with or without functional disability). The variables with $\mathrm{p}<.20$ entered the multiple factor analysis, being considered statistically significant variables when $\mathrm{p}<.05$ in the adjusted analysis, through the backward method. Analyses were performed using the Statistical Package for the Social Sciences (SPSS) version 19.0.

This project was approved by the Human Research Ethics Committee of the State University of Londrina (CAAE No. 0192.0.268.000-10) and the participants signed an informed consent form prior to the interview. 


\section{Results}

Of the total 1339 eligible subjects, 1180 (88.1\%) were interviewed. There were 159 losses (11.9\%), 93 due to refusals and 66 not contacted after at least three attempts at alternative times and dates.

Considering the sample investigated, the age of the subjects varied from 40 to 98 years, with a mean age of $54.6(\mathrm{SD}=10.4)$. The majority of the subjects were female (54.3\%), aged between 40 and 59 years (71.3\%), living with spouse (73.1\%), with less than eight years of education (62.3\%), performing paid work (62\%), living with others $(80.4 \%)$ and belonging to economic class $\mathrm{C}$ or lower (61.8\%). Comparing the characteristics mentioned according to gender, there were higher proportions of men living with a partner, with paid work, living with others and with higher educational and economic levels (Table 1).

Among the mobility criteria evaluated (get up, sit and lie down; walk around the house, walk outside the house, and go up and down stairs), there was a higher prevalence of mild and moderate or severe disability in the older age groups. The most prevalent disability (mild and moderate/severe) was the difficulty of going up and down stairs (24\%), which gradually increased as age increased, $13.2 \%, 23.3 \%, 35.8 \%$ and $49.5 \%$ for those aged 40 to 49 years, 50 to 59 years, 60 to 69 years and 70 and over. respectively (Table 2).

Table 1 - Distribution of the population studied, according to demographic and socioeconomic characteristics. Cambé, 2011

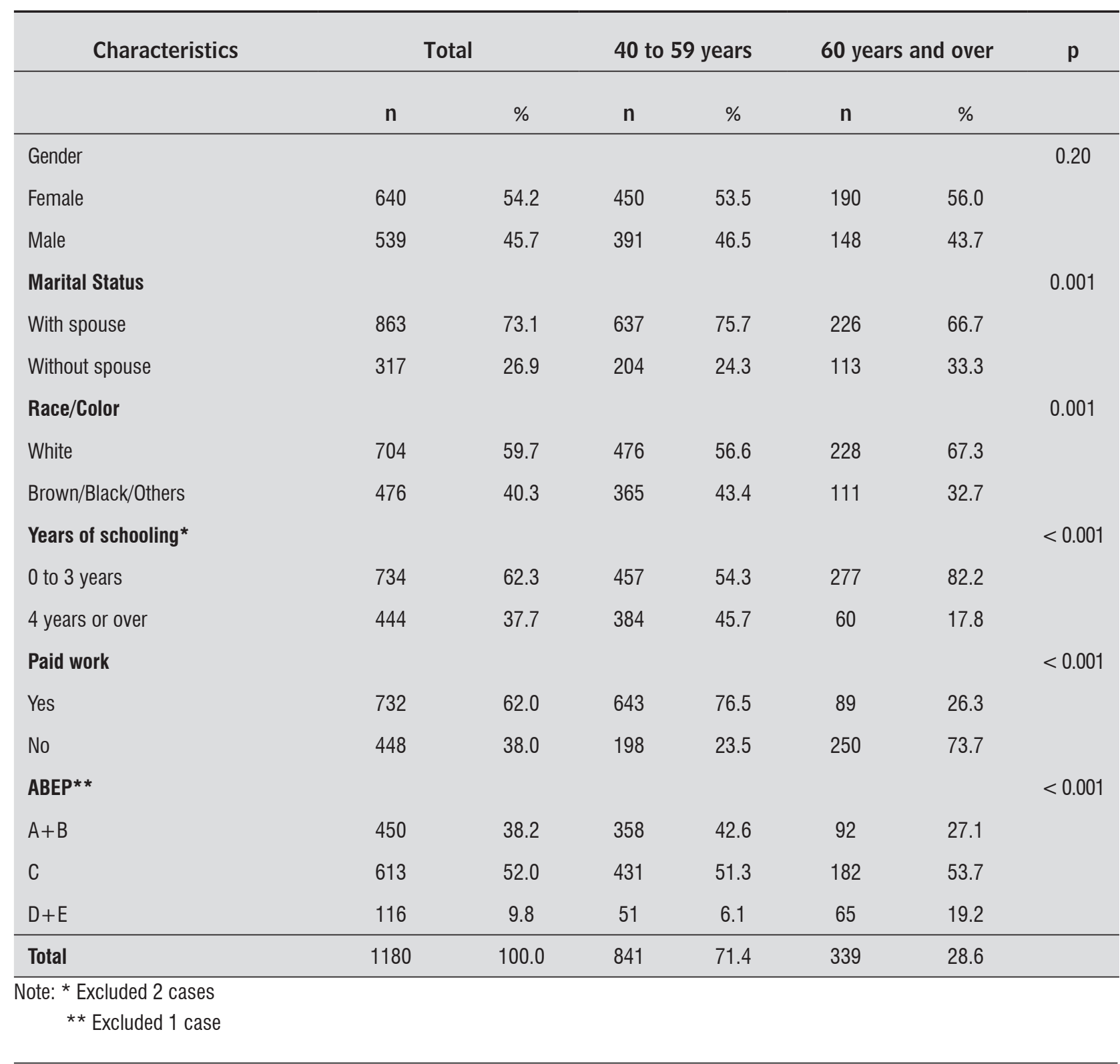


Table 2 - Prevalence of functional disability for mobility, according to age group. Cambé, Paraná, 2011

\begin{tabular}{|c|c|c|c|c|c|c|c|}
\hline \multirow{3}{*}{ Mobility } & \multicolumn{7}{|c|}{ Functional Disability } \\
\hline & \multicolumn{2}{|c|}{ None } & \multicolumn{2}{|c|}{ Wild } & \multicolumn{2}{|c|}{ Moderate/severe } & \multirow[t]{2}{*}{$p^{*}$} \\
\hline & $\mathrm{n}$ & $\%$ & $\mathrm{n}$ & $\%$ & $n$ & $\%$ & \\
\hline Get up, sit and lie down & 1054 & 89.3 & 114 & 9.7 & 12 & 1.0 & $<0.01$ \\
\hline 40 to 49 years & 452 & 95.0 & 23 & 4.8 & 1 & 0.2 & \\
\hline 50 to 59 years & 326 & 89.3 & 38 & 10.4 & 1 & 0.3 & \\
\hline 60 to 69 years & 202 & 84.2 & 33 & 13.8 & 5 & 2.1 & \\
\hline 70 or over & 74 & 74.7 & 20 & 20.2 & 5 & 5.1 & \\
\hline Walk around the house & 1149 & 97.4 & 24 & 2.0 & 7 & 0.6 & $<0.01$ \\
\hline 40 to 49 years & 473 & 99.4 & 3 & 0.6 & - & - & \\
\hline 50 to 59 years & 353 & 96.7 & 11 & 3.0 & 1 & 0.3 & \\
\hline 60 to 69 years & 233 & 97.1 & 3 & 1.3 & 4 & 1.7 & \\
\hline 70 or over & 90 & 90.9 & 7 & 7.1 & 2 & 2.0 & \\
\hline Walk outside the house & $1100^{* *}$ & 93.6 & 59 & 5.0 & 16 & 1.4 & $<0.01$ \\
\hline 40 to 49 years & 465 & 97.7 & 9 & 1.9 & 2 & 0.4 & \\
\hline 50 to 59 years & 339 & 92.9 & 20 & 5.5 & 6 & 1.6 & \\
\hline 60 to 69 years & 217 & 91.6 & 17 & 7.2 & 3 & 1.3 & \\
\hline 70 or over & 79 & 81.4 & 13 & 13.4 & 5 & 5.2 & \\
\hline Go up and down stairs & $896^{* * *}$ & 76.0 & 253 & 21.5 & 30 & 2.5 & $<0.01$ \\
\hline 40 to 49 years & 412 & 86.7 & 59 & 12.4 & 4 & 0.8 & \\
\hline 50 to 59 years & 280 & 76.7 & 76 & 20.8 & 9 & 2.5 & \\
\hline 60 to 69 years & 154 & 64.2 & 80 & 33.3 & 6 & 2.5 & \\
\hline 70 or over & 50 & 50.5 & 38 & 38.4 & 11 & 11.1 & \\
\hline
\end{tabular}

Among those aged 40 to 59 years, in the crude analysis, a higher prevalence was observed in difficulty going up and down stairs among women, aged 50 to 59 years, in subjects with lower educational and economic levels, in those that did not practice any physical activity during leisure time, in those with a history of hypertension, diabetes, cerebrovascular disease, obesity and in those that had fallen in the previous 12 months. After adjustment, the factors that remained associated with the outcome in middle-aged adults were: being female, age group 50-59 years, not performing physical activity during leisure time, having hypertension, DM, CVD and a history of falls in the previous 12 months (Table 3). 
Table 3 - Factors associated with difficulty going up and down stairs in the analysis (crude and adjusted) by Poisson regression in adults aged 40 to 59 years. Cambé, Paraná, 2011

\begin{tabular}{|c|c|c|c|c|c|c|}
\hline \multirow{3}{*}{ Variables } & \multicolumn{6}{|c|}{ Difficulty going up and down stairs } \\
\hline & \multicolumn{2}{|c|}{ Yes } & \multicolumn{4}{|c|}{40 to 59 years } \\
\hline & n & $\%$ & PRb & $\mathrm{p}$ & PRaj & $\mathrm{p}$ \\
\hline Gender & & & & $<0.01$ & & $<0.01$ \\
\hline Female & 116 & 25.8 & $3.14(2.17-4.53)$ & & $2.94(2.06-4.21)$ & \\
\hline Male & 32 & 8.2 & 1 & & 1 & \\
\hline Age & & & & $<0.01$ & & $<0.01$ \\
\hline 70 or over & - & - & - & & - & \\
\hline 60 to 69 years & - & - & - & & - & \\
\hline 50 to 59 years & 85 & 23.3 & $1.75(1.30-2.36)$ & & $1.58(1.18-2.10)$ & \\
\hline 40 to 49 years & 63 & 13.3 & 1 & & 1 & \\
\hline Years of schooling & & & & $<0.01$ & & 0.71 \\
\hline 0 to 3 years & 31 & 26.5 & $1.63(1.16-2.31)$ & & $1.06(0.75-1.51)$ & \\
\hline 4 years or over & 117 & 16.2 & 1 & & 1 & \\
\hline ABEP & & & & $<0.01$ & & 0.07 \\
\hline $\mathrm{D}$ and $\mathrm{E}$ & 17 & 33.3 & $2.83(1.75-4.58)$ & & $1.63(0.97-2.72)$ & \\
\hline C & 89 & 20.6 & $1.75(1.25-2.46)$ & & $1.43(1.01-2.00)$ & \\
\hline$A$ and $B$ & 42 & 11.8 & 1 & & 1 & \\
\hline Physical activity during leisure time & & & & $<0.01$ & & $<0.01$ \\
\hline No & 123 & 20.1 & $1.83(1.22-2.74)$ & & $1.85(1.26-2.71)$ & \\
\hline Yes & 25 & 11.0 & 1 & & 1 & \\
\hline BMI & & & & 0.08 & & 0.45 \\
\hline Obesity & 54 & 22.0 & $1.53(1.04-2.26)$ & & $1.26(0.87-1.83)$ & \\
\hline Overweight & 55 & 17.3 & $1.21(0.82-1.78)$ & & $1.17(0.80-1.69)$ & \\
\hline Normal & 35 & 14.3 & 1 & & 1 & \\
\hline Presence of $\mathrm{HA}$ & & & & $<0.01$ & & 0.01 \\
\hline Yes & 75 & 25.7 & $1.92(1.43-2.56)$ & & $1.40(1.04-1.89)$ & \\
\hline No & 73 & 13.4 & 1 & & 1 & \\
\hline Presence of DM & & & & $<0.01$ & & $<0.01$ \\
\hline Yes & 27 & 36.0 & $2.27(1.61-3.20)$ & & $1.60(1.11-2.31)$ & \\
\hline No & 121 & 15.8 & 1 & & 1 & \\
\hline Presence of DCV & & & & $<0.01$ & & 0.60 \\
\hline Yes & 12 & 57.1 & $3.42(2.29-5.11)$ & & $2.19(1.35-3.55)$ & \\
\hline No & 136 & 16.7 & 1 & & 1 & \\
\hline Musculoskeletal disorders & & & & 0.13 & & $<0.01$ \\
\hline Yes & 46 & 20.9 & $1.26(0.92-1.73)$ & & $1.89(1.37-2.60)$ & \\
\hline No & 102 & 16.5 & 1 & & 1 & \\
\hline Falls & & & & $<0.01$ & & \\
\hline Yes & 35 & 35.4 & $2.30(1.67-3.15)$ & & $1.94(1.40-2.67)$ & \\
\hline No & 112 & 15.4 & 1 & & 1 & \\
\hline
\end{tabular}


Among the people aged 60 or over, in the crude analysis, a higher prevalence was observed in females, in the age group 70 years and over, with lower educational and economic levels, physically inactive during leisure time, with hypertension, cerebrovascular disease and that reported falling in the previous 12 months. In the adjusted analysis, the factors that remained associated with the outcome in the older adults were: being female, not performing physical activity during leisure time and having a history of CVD (Table 4).

Table 4 - Factors associated with difficulty going up and down stairs in the analysis (crude and adjusted) by Poisson regression in the elderly aged 60 or more. Cambé, Paraná, 2011

\begin{tabular}{|c|c|c|c|c|c|c|}
\hline \multirow{3}{*}{ Variables } & \multicolumn{6}{|c|}{ Difficulty going up and down stairs } \\
\hline & \multicolumn{2}{|c|}{ Yes } & \multicolumn{4}{|c|}{60 years or over } \\
\hline & $\mathrm{n}$ & $\%$ & PRb & $\mathbf{p}$ & PRaj & $p$ \\
\hline Gender & & & & $<0.01$ & & $<0.01$ \\
\hline Female & 102 & 53.7 & $2.49(1.78-3.48)$ & & $2.49(1.81-3.43)$ & \\
\hline Male & 32 & 21.6 & 1 & & 1 & \\
\hline Age & & & & 0.01 & & 0.14 \\
\hline 70 or over & 49 & 49.5 & $1.38(1.06-1.79)$ & & $1.19(0.94-1.51)$ & \\
\hline 60 to 69 years & 86 & 35.8 & 1 & & 1 & \\
\hline 50 to 59 years & - & - & - & & - & \\
\hline 40 to 49 years & - & - & - & & - & \\
\hline Years of schooling & & & & 0.02 & & 0.33 \\
\hline 0 to 3 years & 81 & 45.8 & $1.38(1.05-1.81)$ & & $1.14(0.86-1.51)$ & \\
\hline 4 years or over & 53 & 33.1 & 1 & & 1 & \\
\hline ABEP & & & & 0.01 & & 0.77 \\
\hline$D$ and $E$ & 33 & 50.8 & $1.86(1.23-2.81)$ & & $1.16(0.77-1.74)$ & \\
\hline C & 77 & 42.3 & $1.55(1.07-2.26)$ & & $1.10(0.76-1.60)$ & \\
\hline$A$ and $B$ & 25 & 27.2 & 1 & & 1 & \\
\hline Physical activity during leisure time & & & & $<0.01$ & & $<0.01$ \\
\hline No & 106 & 46.1 & $1.73(1.23-2.43)$ & & $1.62(1.17-2.25)$ & \\
\hline Yes & 29 & 26.6 & 1 & & 1 & \\
\hline BMI & & & & 0.67 & & \\
\hline Obesity & 41 & 41.0 & $0.95(0.68-1.32)$ & & $1.03(0.77-1.37)$ & 0.33 \\
\hline Overweight & 47 & 37.3 & $0.86(0.63-1.19)$ & & $0.83(0.62-1.12)$ & \\
\hline Normal & 43 & 43.0 & 1 & & 1 & \\
\hline Presence of $\mathrm{HA}$ & & & & $<0.01$ & & \\
\hline Yes & 99 & 47.1 & $1.66(1.21-2.27)$ & & $1.33(0.99-1.79)$ & 0.05 \\
\hline No & 36 & 28.3 & 1 & & 1 & \\
\hline Presence of DM & & & & 0.59 & & \\
\hline Yes & 27 & 42.9 & $1.09(0.79-1.50)$ & & $0.97(0.72-1.31)$ & 0.85 \\
\hline No & 108 & 39.3 & 1 & & 1 & \\
\hline Presence of DCV & & & & $<0.01$ & & \\
\hline Yes & 15 & 78.9 & $2.09(1.59-2.74)$ & & $2.25(1.65-3.08)$ & $<0.01$ \\
\hline No & 120 & 37.7 & 1 & & 1 & \\
\hline Musculoskeletal disorders & & & & 0.69 & & \\
\hline Yes & 50 & 41.3 & $1.05(0.80-1.38)$ & & $1.00(0.77-1.30)$ & 0.97 \\
\hline No & 85 & 39.2 & 1 & & 1 & \\
\hline Falls & & & & 0.01 & & 0.05 \\
\hline Yes & 37 & 52.1 & $1.42(1.08-1.87)$ & & $1.27(0.99-1.62)$ & \\
\hline No & 97 & 36.5 & 1 & & 1 & \\
\hline
\end{tabular}




\section{Discussion}

The prevalence of mild or moderate/severe functional disability in the four mobility indicators evaluated ranged from $2.6 \%$ (for difficulty walking around the house) to $24 \%$ (for difficulty going up and down stairs). However, one of the most important results observed was that these disabilities, although progressively increasing with advancing chronological age, affecting a significant proportion of people from 40 years of age. In addition, when considering the difficulty going up and down stairs outcome, the fact that this does not remain associated with the age group variable in people aged 60 years or over after the adjusted analysis reinforces the idea that aging does not necessarily lead to an accumulation of disabilities. Therefore, this reflects, as with other chronic diseases (21), the intensity and duration of exposure to other risk factors such as comorbidities, which can lead to dysfunctions.

The prevalence of difficulty going up and down stairs found in this study (24\%) was higher than that found in other studies, in which the prevalence ranged from $10 \%$ to $20 \%$. However, it is difficult to draw comparisons, since most of these studies examined other age groups and used different methods $(2,13,22,23)$.

The association between difficulty going up stairs and being female is consistent with other national and international studies $(10,12,13,14,15)$. The higher prevalence among women can be attributed, in part, to the greater ability of women to report their health conditions than men (13). However, this may also be due to gender differences in body composition and physical fitness, in which women, due to their greater proportion of body fat, lower proportion of lean body mass and lower aerobic capacity than men, tend to present lower performance of physically demanding activities, especially involving the lower limbs (24).

The study reinforces the idea that moderate and high levels of physical activity appear to reduce the risk of disability or functional limitations (25), especially considering the association between the non-performance of physical activity during leisure time and functional disability. Even though this finding is subject to reverse causality, since the interviewees could not be active during leisure time precisely because of their low functional capacity, studies have indicated regular physical activity as a desirable behavior for health that can contribute to the maintenance and improvement of the functional capacity $(26,27)$.
The report of cerebrovascular disease was the second best predictor of disability analyzed in both age groups in this study. This finding, concurrent with other studies $(28,29,30)$, is of importance when considering that, even though it is one of the leading health problems in Latin America and the Caribbean (31), having an impact on the physical and psychological well-being of the people affected and their family members (32), the majority of the cases could be prevented with proper control of its risk factors.

The report of hypertension, DM and history of falls in the previous 12 months remained associated with the difficulty of going up and down stairs only for individuals of 40 to 59 years in this study. Hypertension has a high prevalence and low rates of control and is considered one of the major modifiable risk factors for cardiovascular disease in Brazil (VI Brazilian Guidelines on Hypertension) (33). Failure to control and treat this disease allow the installation of other diseases, such as coronary artery disease, acute myocardial infarction and diabetes, which have a strong negative impact on the physical function of individuals with hypertension (34).

The presence of DM also appears as worrying aspect. One study of individuals aged 60 years and over in the United States noted that $32 \%$ of women and $15 \%$ of men with diabetes reported an inability to walk $1 / 4$ mile, climb stairs or clean the house (35). In addition, DM, due to being associated with microvascular and macrovascular complications, such as peripheral neuropathy, which is related to low levels of physical performance (36) and pain, greatly affects the quality of life of patients (37). According to Wray et al. (38), DM was shown to be a significant predictor of disability, not only in the older adults, but also in middle-aged people.

Diabetes and sarcopenia have been reported as risk factors for the development and/or progression of physical disability among individuals. According to Anton et al. (39), diabetes seems to accelerate the progression of sarcopenia due to metabolic dysregulation, contributing to the progressive loss of strength and muscle mass.

In the present study the association observed between falls and difficulty going up and down stairs is consistent with the results of other studies $(40,41$, $42,43)$. According to Melzer, Gardener and Guralnik (22), the limitation in the mobility in individuals due to pain in the lower limbs (hip, knee and foot) or spine, is a significant finding for the identification 
of measures that require prevention, treatment and rehabilitation. Accordingly, to preserve bone and muscle mass and to reduce excess fat and levels of physical inactivity are important strategies for the maintenance of physical performance and for the reduction of functional disability in individuals (44).

However, these results and the others should be analyzed with caution, since the main limitation of the present study is its cross-sectional design, in which there is no possibility to infer causality between functional disability and the independent variables. Furthermore, the self-reported data may have increased the sensitivity of the measurements. However, according to Fried et al. (11), this measure is considered a reliable indicator for the risk of disability, as it allows for assistance or for the caregivers to answer the questions of the form. It should be noted that in this study only $1.5 \%$ of the interviews were not answered by the selected subject. Another relevant aspect to be considered is the difficulty in establishing a comparison between the results of this study and those of other studies, due to variations in the measures, scales, dimensions and classifications and the lack of standardization in the evaluation of the functional disability. Furthermore, the majority of the studies restrict their analysis to older adults, unlike this study that included people from the age of 40 years.

It is therefore likely that the variables that remained significant in the adjusted analysis are related to functional decline and the various factors that remained associated confirm the multifactorial nature of the analyzed outcome and reiterate the importance of the challenge to the Brazilian health system with the expansion of strategies for coping with diseases and non-communicable injuries, as proposed by the Ministry of Health (45). Although this study presented limitations, the analysis of the prevalence of functional disability for mobility and factors associated with the activity of going up and down stairs in the population from the age of 40 years (with a higher prevalence in females, obesity, history of chronic and musculoskeletal diseases and among those who did not perform physical activity, did not perform paid work and were in worse economic conditions) shows that the prevention of functional disability necessarily entails interventions in the different cycles of life.

Due to being a population-based study, these results show the fundamental aspects that should be considered in the formulation and implementation of intersectoral public policies. It indicates that to prevent functional disability, which affects not only older adults and can be detected in a preclinical stage, the performance of physical activities that preserve muscle mass and the effective control of chronic conditions should be encouraged. These actions should be integrated into the priority agenda of the healthcare services, especially those directed toward primary healthcare and the inclusion of economically disadvantaged populations.

\section{Acknowledgements}

The authors thank CAPES (PROAP, Equipment grant and Master's scholarship) and of the Municipal Health Secretariat of Cambé.

\section{References}

1. Alves LC, Leite IC, Machado CJ. Conceituando e mensurando a incapacidade funcional da população idosa: uma revisão de literatura. Cien Saude Colet. 2008;13(4):1199-207.

2. Iezzoni LI, McCarthy EP, Davis RB, Siebens H. Mobility difficulties are not only a problem of old age. J Gen Intern Med. 2001;16:235-43.

3. Lollar DJ, Crews JE. Redefining the role of public health in disability. Annu Rev Public Health. 2003;(24):195-208.

4. Verbrugge LM, Jette AM. The Disablement Process. Soc Sci Med. 1994;38(1):1-14.

5. Guralnik JM, Fried LP, Salive ME. Disability as a public health outcome in the aging population. Annu Rev Public Health. 1996;17:25-46.

6. Fried LP, Guralnik JM. Disability in older adults: evidence regarding significance, etiology, and risk. J Am Geriatr Soc. 1997;45:92-100.

7. Avlund K, Pedersen AN, Schroll M. Functional decline from age 80 to 85: influence of preceding changes in tiredness in daily activities. Psychosom Med. 2003;65:771-7.

8. Chen H, Wang C, Lee M, Tang P, Chu Y, Suen M. A hierarchical categorisation of tasks in mobility disability Disabil Rehabil. 2010;32(19):1586-93.

9. Gretebeck RJ, Ferraro KF, Black DR, Holland K, Gretebeck KA. Longitudinal change in physical activity and disability in adults. Am J Health Behav. 2012;36(3):385-94. 
10. Leveille SG, Penninx BWJH, Melzer D, Izmirlian G, Guralnik JM. Sex differences in the prevalence of mobility disability in old age: the dynamics of incidence, recovery, and mortality. J Geront B Psychol Sci Soc Sci. 2000;55(1):S41-S50.

11. Fried LP, Bandeen-Roche K, Chaves PHM, Johnson BA. Preclinical Mobility Disability Predicts Incident Mobility Disability in Older Women. J Gerontol A Biol Sci Med Sci. 2000;55(1):M43-M52.

12. Gill TM, Allore HG, Hardy SE, Guo Z. The dynamic nature of mobility disability in older persons. J Am Geriatr Soc. 2006;54:248-54.

13. Parahyba MI, Simões CCS. A prevalência de incapacidade funcional em idosos no Brasil. Cien Saude Colet. 2006;11(4):967-74.

14. Parahyba MI, Veras R. Diferenciais sociodemográficos no declínio funcional em mobilidade física entre os idosos no Brasil. Cien Saude Colet. 2008;13(4):1257-64.

15. Alves LC, Leite IC, Machado CJ. Fatores associados à incapacidade funcional dos idosos no Brasil: análise multinível. Rev Saude Publica. 2010;44(3):468-78.

16. Departamento de Informática do SUS. Informações de Saúde. Estatísticas Vitais. Mortalidade Geral - Paraná. 2007. Óbitos por residência segundo capítulo da CID10. [cited 2007]. Available from: http://tabnet.datasus.gov.br/cgi/tabcgi.exe?sim/cnv/obtpr.def

17. Souza RKT, Bortoletto MSS, Loch MR, González AD, Matsuo T, Cabrera MAS, et al. Prevalência de fatores de risco cardiovascular em pessoas com 40 anos ou mais de idade, da cidade de Cambé, Estado do Paraná, Brasil (2011): estudo de base populacional. Epidemiol Serv Saude. 2013;22(1):95-102.

18. Desrosiers J, Bravo G, Hébert R, Dubuc N. Reliability of the revised functional autonomy measurement system (smaf) for epidemiological research. Age Ageing. 1995;24:402-6.

19. Associação Brasileira de Empresas de Pesquisa. Critério de Classificação Econômica Brasil (CCEB): em vigor a partir de 01/01/2010. Available from: http:// www.abep.org/novo/Content.aspx?ContentID=301

20. World Health Organization. Obesity: preventing and manging the global epidemic - report of a WHO consultation on obesity. Geneve: World Health Organization; 2000.
21. Dhingra R, Vasan RS. Age as a risk factor. Med Clin N Am. 2012;96:87-91.

22. Melzer D, Gardener E, Guralnik JM. Mobility disability in the middle-aged: cross-sectional associations in the English Longitudinal Study of Ageing. Age Ageing. 2005;34:594-602.

23. Gardener EA, Huppert FA, Guralnik JM, Melzer D. Middle-aged and mobility-limited: prevalence of disability and symptom attributions in a national survey. J Gen Intern Med. 2006;21:1091-6.

24. Valentine RJ, Misic MM, Rosengren KS, Woods JA, Evans EM. Sex impacts the relation between body composition and physical function in older adults. Menopause. 2009;16(3):518-23.

25. Paterson DH, Warburton DER. Physical activity and functional limitations in older adults: a systematic review related to Canada's Physical Activity Guidelines. Int J Behav Nutr Phys Act. 2010;7(38):1-22.

26. Mendes EV. O cuidado das condições crônicas na atenção primária à saúde: o imperativo da consolidação da estratégia da saúde da família. Brasília (Brazil): Organização Pan-Americana da Saúde; 2012. 512 p.

27. Lang IA, Guralnik JM, Melzer D. Physical activity in middle-aged adults reduces risks of functional impairment independent of its effect on weight. J Am Geriatr Soc. 2007;55(11):1836-41.

28. Teasel R. Stroke recovery and rehabilitation. Stroke. 2003;34:365-9.

29. Giacomin KC, Peixoto SV, Uchoa E, Lima-Costa MF. Estudo de base populacional dos fatores associados à incapacidade funcional entre idosos na Região Metropolitana de Belo Horizonte, Minas Gerais, Brasil. Cad Saude Publica. 2008;24(6):1260-70.

30. Nunes MCR, Ribeiro RCL, Rosado LEFPL, Franceschini SC. Influência das características sociodemográficas e epidemiológicas na capacidade funcional de idosos residentes em Ubá, Minas Gerais. Rev Bras Fisioter. 2009;13(5):376-82.

31. Lavados PM, Hennis AJM, Fernandes JG, Medina MT, Legetic B, Hoppe A, et al. Stroke epidemiology, prevention, and management strategies at a regional level: Latin America and the Caribbean. Lancet Neurol. 2007;6(4):362-72. 
32. Shah MV. Rehabilitation of the older adult with stroke. Clin Geriatr Med. 2006;22(2):469-89.

33. VI Diretrizes Brasileiras de Hipertensão. Rev Bras Hipertens. 2010;17(1):1-64.

34. Suciu L, Cristescu C, Tomescu M, Balaş M, Mureşan R, Vlaia V, et al. The impact of hypertension and associated comorbidities on quality of life assessment questionnaire SF-36 V2. Farmacia. 2013;61(3):503-17.

35. Gregg EW, Beckles GL, Williamson DF, Leveille SG, Langlois JA, Engelgau MM, et al. Diabetes and physical disability among older U.S. adults. Diabetes Care. 2000;23:1272-7.

36. Tuttle LJ. Skeletal muscle impairments in people with diabetes and peripheral neuropathy [dissertation]. Saint Louis (MO): Washington University in St. Louis; 2011. 147 p. English.

37. Davies M, Brophy S, Williams R, Taylor A. The prevalence, severity, and impact of painful diabetic peripheral neuropathy in type 2 diabetes. Diabetes Care. 2006;29:1518-22.

38. Wray LA, Ofstedal MB, Langa KM, Blaum CS. The effect of diabetes on disability in middle-aged and older adults. J Gerontol A Biol Sci Med Sci. 2005;60(9):1206-11.

39. Anton SD, Karabetian C, Naugle K, Buford TW. Obesity and diabetes as accelerators of functional decline: Can lifestyle interventions maintain functional status in high risk older adults? Exp Gerontol. 2013;48(9):888-97.

40. van Dijk GM, Dekker J, Venhoof C, van den Ende CHM. Course of functional status and pain in osteoarthritis of the hip or knee: a systematic review of the literature. Arthritis Rheum. 2006;55(5):779-85.

41. Hébert R, Brayne C, Spiegelhalter D. Factors associated with functional decline and improvement in a very elderly community-dwelling population. Am J Epidemiol. 1999;150(5):501-10.

42. Tas Ü, Verhagen AP, Bierma-Zeinstra SMA, Hofman A, Odding E, Pols HAP, et al. Incidence and risk factors of disability in the elderly: The Rotterdam Study. Prev Med. 2007;44:272-8.
43. Piirtola M, Löppönen M, Vahlberg T, Isoaho R, Kivelä L, Räihä I. Fractures as an independent predictor of functional decline in older people: a populationbased study with an 8-year follow-up. Gerontology. 2012;58(4):296-304.

44. Shin H, Panton LB, Dutton GR, Ilich JZ. Relationship of physical performance with body composition and body mineral density in individuals over 60 years of age: a systematic review. J Aging Res. 2011;2011:191896.

45. Ministério da Saúde. Secretaria de Vigilância em Saúde. Departamento de Analise de Situação de Saúde. Plano de ações estratégicas para o enfrentamento das doenças crônicas não transmissíveis (DCNT) no Brasil 2011-2022. Brasília: Ministério da Saúde; 2011. 160 p.

Received in $08 / 05 / 2014$

Recebido em 05/08/2014

Approved in 10/08/2015 Aprovado em 08/10/2015 
